\title{
Pengaruh Model Pembelajaran Treffinger Berbantuan Media Gambar terhadap Kreativitas dan Hasil Belajar Siswa pada Materi Sistem Peredaran Darah
}

\author{
Iva Malini*, Nanik Lestariningsih, Ridha Nirmalasari \\ Program Studi Tadris Biolgi, IAIN Palangka Raya, Indonesia \\ *ivamalini27@gmail.com
}

\begin{abstract}
Abstrak
Penelitian ini bertolak dari pembelajaran konvesional berpusat pada guru yang mempengaruhi hasil belajar siswa. Oleh karena itu, penelitian ini bertujuan untuk mengetahui pengaruh pembelajaran treffinger berbantuan media gambar terhadap hasil belajar, mendeskripsikan kreativitas siswa, serta keterterapannya. Penelitian kuantitatif ini dengan jenis quasi eksperimen, dan dilakukan di suatu SMP Negeri Palangka Raya pada materi sistem peredaran darah. Purposive sampling merupakan teknik pengembilan sampel sehingga sampel penelitian ini adalah siswa kelas VIII. Berdasarkan hasil penelitian, terdapat pengaruh pembelajaran treffinger berbantuan media gambar terhadap hasil belajar siswa. Hal ini disimpulkan dari hasil analisis data menggunakan independent samples $t$-test bahwa $p$-value $=0,000<0,05=\alpha$. Hasil analisis data kreativitas siswa kelompok pembelajaran treffinger berbantuan media gambar bahwa keseluruhan nilainya sebesar $78 \%$ sehingga persentase tersebut termasuk dalam kriteria sedang. Keterterapan model pembelajaran treffinger berbantuan media gambar termasuk dalam kriteria sangat baik dengan nilai pertemuan pertama $84,25 \%$ dan pertemuan kedua $97,5 \%$. Dengan demikian, dapat disimpulkan bahwa terdapat pengaruh model pembelajaran treffinger berbantuan media gambar terhadap hasil belajar dan kreativitas siswa.
\end{abstract}

Kata kunci: kreativitas, sistem peredaran darah, treffinger.

Dikirim: 17 September 2021

Direvisi: 01 Oktober 2021

Diterima: 16 Oktober 2021

\section{Identitas Artikel:}

Malini, I., Lestariningsih, N., \& Nirmalasari, R. (2022). Pengaruh Model Pembelajaran Treffinger Berbantuan Media Gambar terhadap Kreativitas dan Hasil Belajar Siswa pada Materi Sistem Peredaran Darah. Jurnal Ilmu Pendidikan (JIP) STKIP Kusuma Negara, 13(2), 109-119.

\section{PENDAHULUAN}

Siswa dianggap sebagai titik pusat dan subjek yang dikembangkan dalam proses pembelajaran yang mereka peroleh. Guru berperan motivasi dan fasilitator dalam proses belajarnya siswa dan menaruh keleluasaan siswa buat menerima pengetahuan belajarnya siswa dan menaruh keleluasaan siswa buat menerima pengetahuan belajarnya tersebut yang sepadan dengan keperluannya dan juga kemampuannya. Guru selanjutnya mesti menguasai beragam model pembelajaran yang dipergunakan untuk menuju ke tujuan pembelajaran yang dicapai, sebab model pembelajaran pada patokannya proses pembelajaran bagi guru untuk membuat interaksi dalam proses belajar mengajar agar lebih efisien (Arikunto, 2006).

Informasi dan sumber belajar difasilitasi aktivitas pembelajaran oleh guru yang sebagai tenaga pengajar yang profesional. Guru profesional akan memahami serta mahir penggunakan berbagai macam model pengajaran. Menggunakan berbagai 
model pembelajaran dapat peningkatan kualitas dan kreativitas para siswa. Indikator ketercapaiannya guru dalam suatu pembelajaran dengan mengubahnya sikap yang lebih baik dari siswa tersebut setelah menghadapi proses pembelajaran, oleh sebab itu, guru butuh merencanakan model pembelajaran yang melibatkan siswa agar mencapai indikator tersebut (Mahmud \& Idham, 2017).

Menurut Sanjaya (2008) pelaksanaan suatu pembelajaran juga tidak dapat diwujudkan tanpa adanya suatu tujuan atau arah yang akan dicapai. Tujuan pendidikan itu sendiri tertera pada UU No. 20 tahun 2003 (dalam Sugiyono, 2019) diterangkan bahwa tujuan pendidikan nasional untuk berkembangnya potensi siswa agar menjadi manusia yang cakap, berakhlak mulia, beriman dan bertakwa kepada Tuhan Yang Maha Esa, menjadi warga negara yang demokratis, mandiri, berilmu, sehat, dan bertanggung jawab serta kreatif. Salah satu tujuan yang terdapat pada pendidikan nasional yaitu untuk mewujudkan siswa yang kreatif. Menurut Cahyaningsih dan Ghufron, (2016) sikap kreatif itu akan tumbuh dalam diri seseorang apabila ia terlatih, terbiasa dari kecil untuk mengeksplorasi, dan memberikan gagasan, ide, dan memecahkan masalah.

Kreativitas adalah keterampilan penalaran sederhana. Keterampilan penalaran meliputi orisinalitas, keluwesan spontanitas, kelancaran berpikir, serta kelancaran berbicara (Abdussalam, 2005). Kreativitas adalah keterampilan menyampaikan gagasan-gagasan yang baru, keterampilan untuk melihat keterkaitan baru dan unsur-unsur yang sudah ada (Munandar, 1992). Jadi, berdasarkan uraian tersebut, kreativitas adalah suatu proses untuk memberikan gagasan-gagasan dengan kemampuan nalarnya yang dipergunakan waktu mengemukakan ide baru dengan menggabungkan dengan ide sebelumnya yang mencerminkan keluwesan, kelancaran, serta kemampuan untuk menghasilkan gagasan.

Menurut Costa (2001) dan Jazuli (2009) kreativitas berkaitan pada berpikir kreatif, karena hasil dari proses berpikir kreatif seseorang itu merupakan kreativitas. Oleh karena itu, pendidikan harus menumbuhkan kreativitas dalam mengembangkan potensi siswa. Pengembangan siswa melalui pembelajaran yang merangsang kemampuan berpikir kreatif.

Mengembangkan suatu keterampilan siswa dalam berpikir kreatif, mengajak mereka mengemukakan pemikiran mereka yang berbeda dengan yang dikemukakan oleh temannya. Guru harus mendorong siswa berpikir kreatif dengan keterampilan sikap yang melibatkan siswa dalam berpikir kreatif serta pemecahan masalah. Guru dapat mengajari siswa cara bertukar pikir. Teknik pemecahan masalah kreatif yang melibatkan banyak orang yang dimaksud dari tukar pikiran tersebut. Siswa melalui tukar pikiran dapat menggabungkan serta melengkapi ide pemikiran orang lain serta menghasilkan lebih banyak ide (Davis, 2012).

Menurut Insyasiska, Zubaidah dan Susilo (2017) mengatakan kemampuan kreatif memiliki sifat yang positif untuk peningkatkan hasil belajar kognitif siswa, yang membuat menambah tinggi hasil belajarnya siswa dan kemampuan berpikir kreatif siswa tersebut tinggi juga. Menurut Siswono dan Novitasari (2007) yang mengatakan bahwa untuk peningkat keterampilan berpikir kreatif siswa pada proses pembelajaran diciptakan peluang untuk berkembangnya kreativitas siswa. Diharapkan Ketika siswa mengembangkan keterampilan berpikir kreatif, mereka akan mampu memecahkan masalahnya sendiri. Hal ini dikarenakan dalam berpikir kreatif, siswa dapat menggunakan informasi sebelumnya dengan informasi yang diterima dari guru kemudian, informasi tersebut digabungkan sehingga siswa 
mendapatkan informasi terbaru dan dapat memecahkan masalah yang akan dihadapinya.

Berdasarkan dalam wawancara Bersama guru bidang studi SMP Negeri 8 Palangka Raya diketahui bahwa pelajaran IPA di SMP Negeri 8 Palangka Raya Kriteria Ketuntasan Minimal (KKM) yaitu 65. Model pembelajaran yang digunakan guru masih kurang bervariasi, dan hanya menggunakan model pembelajaran itu-itu saja, seperti masih menggunakan model pembelajaran konvensional. Sehingga siswa hanya duduk, mencatat, dan mendengarkan apa yang disampaikan oleh guru saja. Dengan demikian, suasana pembelajaran menjadi tidak kondusif, membuat aktivitas siswa menjadi terbatas dan kurang terlibat dalam proses pembelajaran. Kemudian pada saat pembelajaran, ketika siswa menjawab soal, siswa masih berfokus dan nyalin dari apa yang tertulis di buku maupun internet, siswa belum mengembangkan pembelajarannya dengan bahasa mereka sendiri hal itulah yang menyebabkan siswa tidak kreatif untuk memunculkan ide dan gagasan mereka tersebut dalam suatu pembelajaran. Bagi siswa SMP Negeri 8 Palagka Raya salah satu materi pelajaran yang sulit yaitu materi sistem peredaran darah tersebut bersifat abstrak sehingga sulit untuk melihat secara langsung organorgan serta proses-proses yang terjadi yang tidak dapat dilihat langsung oleh siswa tersebut.

\section{METODE PENELITIAN}

Di Sekolah Menengah Pertama Negeri 8 Palangka Raya tempat pelaksanaan penelitian beralamat di Jalan Tilung, Kota Palangka Raya, Kalimantan Tengah, pada semester genap 2021 dengan materi sistem peredaran darah. Populasi pada penelitian ini yaitu seluruh siswa kelas VIII SMP Negeri 8 Palangka Raya. Setelah itu, peneliti mengambil sampel siswa pada kelas VIII-7 dan VIII-8. Kelas VIII-7 berjumlah 33 siswa sebagai kelas eksperimen dan kelas VIII-8 berjumlah 32 sebagai kelas kontrol, dengan menggunakan teknik Purposive sampling. Kemudian, jenis penelitiannya yaitu quasi eksperimen dengan design pretestposttest control group design, Adapun rancangan desain yang digunakan, yaitu sebagai berikut.

Tabel 1. Desain penelitian

\begin{tabular}{cccc}
\hline Kelompok & Pretes & Perlakuan & Postes \\
\hline $\mathrm{E}$ & $\mathrm{Y}_{1}$ & $\mathrm{X}_{1}$ & $\mathrm{Y}_{2}$ \\
$\mathrm{~K}$ & $\mathrm{Y}_{1}$ & - & $\mathrm{Y}_{2}$ \\
\hline
\end{tabular}

Keterangan: $\mathrm{E}=$ kelompok eksperimen, $\mathrm{K}=$ kelompok kontrol, $\mathrm{X}_{1}=$ perlakuan model pembelajaran treffinger berbantuan media gambar, $\mathrm{Y}_{1}=$ pretes (tes awal), $\mathrm{Y}_{2}=$ postes (tes akhir).

Intrumen penelitian diuji dengan (1) uji validitas (2) uji reliabilitas (3) uji daya beda (4) uji tingkat kesukaran. Teknik analisis data yaitu berupa (1) Analisis statistik deskriptif (2) Analisis statistik inferensial 


\section{HASIL DAN PEMBAHASAN}

\section{Pengaruh Model Pembelajaran terhadap Hasil Belajar Siswa}

Analisis Statistik Deskriptif digunakan untuk mengetahui hasil belajar siswa Ketika diberikannya perlakuan berupa penggunaan model pembelajaran treffinger dengan data deskriptif berupa Tabel distribusi dari nilai minimum, nilai maksimum, ratarata, median, modus dan standar deviasi.

Dalam penelitian ini, hasil belajarnya siswa dinilai dengan tes pilihan ganda kemudian untuk soal berjumlah 40, dilakukannya pretes serta postes. Tabel 2 menunjukkan bahwa rata-rata nilai sebelum dan sesudah perlakuan pada kelas eksperimen mengalami perbedaan. Pada Gambar 1, data yang dihasilkan dari kelas eksperimen dan kontrol.

Tabel 2. Analisis Data Pretes dan Postes Hasil belajar Siswa

\begin{tabular}{lcccc}
\hline \multirow{2}{*}{ Statistika } & \multicolumn{4}{c}{ Nilai Statistika } \\
\cline { 2 - 5 } & Kelas Eksperimen & Kelas Kontrol \\
\cline { 2 - 5 } & Pretes & Postes & Pretes & Postes \\
\hline Jumlah Siswa & 33 & 33 & 32 & 32 \\
Mean & 47,65 & 75,62 & 43,05 & 59,14 \\
Median & 47,5 & 75 & 42,5 & 58,75 \\
Nilai modus & 47,5 & 75 & 42,5 & 50 \\
Standar Deviasi & 9,415 & 6,027 & 10,428 & 6,494 \\
Nilai Minimum & 30 & 65 & 22,5 & 50 \\
Nilai Maksimum & 67,5 & 88 & 62,5 & 70 \\
\hline
\end{tabular}

Gambar 1 ditunjukkan kelas eksperimen mengalami peningkatan hasil belajar lebih signifikan dibanding kelas kontrol. Nilai rata-rata saat pretes dapat dilihat pada hal tersebut yaitu 47,65 dan rata-rata pada saat postes mengalami peningkatan menjadi 75,62. Model pembelajaran treffinger berbantuan media gambar yang diterapkan di kelas eksperimen selama proses pembelajaran yang telah membantu siswa lebih kreatif.

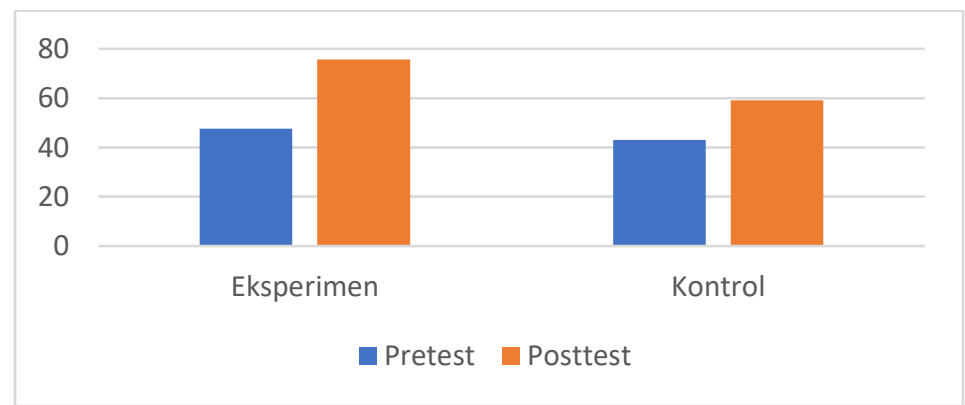

Gambar 1. Skor Rata-rata Pretes dan Postes

Huda (2013) menyatakan model pembelajaran treffinger dapat membuat siswa untuk memacu gagasan-gagasan kreatif, mengembangkan kelenturan berpikir, bersikap kreatif, kelancaran, bersikap, dan mengembangkan masalah yang nyata serta kompleks. Selain itu, menurut Juniantari (2017), model pembelajaran treffinger memiliki karakteristik yaitu menanamkan siswa sebagai seseorang yang aktif dalam memecahkan masalah dalam suatu permasalahan. Sedangkan untuk kelas kontrol terhadap peningkatan nilai siswa pretes postes dengan rata-rata yaitu 
43,05 pada saat pretes dan rata-rata pada saat postes sebesar 59,14. Kemudian untuk analisis statistik inferensial yang digunakan dalam penelitian ini adalah sebagai berikut, termasuk uji prasyarat analisis.

Sebelum uji hipotesis dilaksanakan, terlebih dahulu dilakukan uji prasyarat data, yaitu menguji nomalitas dan homogenitas. Berikut Tabel 3, rangkuman hasil analisis uji normalitas data.

\begin{tabular}{|c|c|c|c|}
\hline \multirow{2}{*}{ Kelas } & \multicolumn{2}{|c|}{ Sig. $>\alpha=0,05$} & \multirow{2}{*}{ Keterangan } \\
\hline & Pretes & Postes & \\
\hline Eksperimen & 0,052 & 0,200 & Normal \\
\hline Kontrol & 0,088 & 0,088 & Normal \\
\hline
\end{tabular}

Berdasarkan Tabel 3, nilai signifikansi kelas eksperimen pada pretes yaitu 0,052 dan postes 0,200. Kemudian, nilai signifikansi kelas kontrol pada pretes adalah 0,088 dan pada postes 0,088 . Dengan demikian, data dari kelas eksperimen dan kelas kontrol berdistribusi normal sebab nilai signifikansinya lebih besar daripada 0,05. Hasil tersebut sejalan dengan pendapat Nuryadi dkk. (2017) bahwa pedoman pengambilan uji normalitas yaitu jika signifikansi ( $p$-value) lebih dari 0,05 data tersebut berdistribusikan normal jika nilai signifikansi ( $p$-value) kurang dari 0,05 data tersebut maka tidak berdistribusi normal.

Tahap selanjutnya adalah uji homogenitas. Berikut adalah Tabel 4, yaitu hasil analisis Levene statistic.

Tabel 4. Hasil Uji Homogenitas Data

\begin{tabular}{lcc}
\hline Hasil Belajar & Sig. & Keterangan \\
\hline Pretes & 0,489 & Homogen \\
Postes & 0,256 & Homogen \\
\hline
\end{tabular}

Berdasarkan Tabel 4, perhitungan penggunakan program SPSS, memperolehkan nilai signifikansi pada pretes yaitu 0,489 serta 0,256 untuk postes. Dari hal tersebut, disimpulkan bahwa berdasarkan pedoman pengambilan keputusan uji homogenitas yaitu apabila nilai Sig. lebih dari 0,05 sehingga dikatakan variasi data itu merupakan homogen.

Selanjutnya adalah perhitungan analisis data untuk uji hipotesis penelitian apakah terdapat pengaruh model pembelajaran treffinger berbantuan media gambar terhadap hasil belajar siswa. Rangkuman hasil analisisnya disajikan dalam Tabel 5.

Tabel 5. Hasil Uji Hipotesis Data Hasil Belajar Siswa

\begin{tabular}{ccccc}
\hline Mean Difference & $t$ & $d f$ & Sig. & Std. Error Difference \\
\hline 16,48059 & 10,609 & 63 & 0,000 & 1,55351 \\
\hline
\end{tabular}

Berdasarkan Tabel 5, uji hipotesis dengan independent samples t-test dalam SPSS. Uji hipotesis diketahui nilai Sig. (2-tailed) lebih kecil daripada 0,05 (0,000 $<0,05$ ) sehingga ada perbedaannya signifikan (nyata) hasil belajar siswa kelas eksperimen dan kelas kontrol. Bahwa sehingga dapat disimpulkan terdapat pengaruh model pembelajaran treffinger berbantuan media gambar terhadap hasil belajar. Hasil tersebut sejalan dengan kriteria uji hipotesis menurut Muhson (2016) 
dimana nilai Sig. (2-tailed) lebih dari 0,05 maka $\mathrm{H}_{0}$ diterima dan $\mathrm{H}_{\mathrm{a}}$ ditolak dan jika nilai Sig. (2-tailed) kurang dari 0,05 maka $\mathrm{H}_{0}$ ditolak dan $\mathrm{H}_{\mathrm{a}}$ diterima. Penelitian tersebut sejalan pada hasil penelitian sebelumnya yang menunjukkan treffinger mempunyai pengaruh terhadap meningkatnya hasil belajar siswa. Rahmawati, Kurniawan dan Ashari (2015) serta Muliyani, Leny dan Suharto, (2017) menyatakan bahwa model pembelajaran treffinger berpengaruhnya pada hasil belajar siswa karena siswa yang diajari dengan penggunaan model pembelajaran treffinger mengalami peningkatan terhadap hasil belajarnya.

\section{Kreativitas Siswa dengan Model Pembelajaran Treffinger}

Kreativitas siswa dengan treffinger dilakukan menggunakan angket. Angket diberikan kepada kelas eksperimen yang memperoleh perlakuan model pembelajaran treffinger berbantuan media gambar. Berikut persentase skor kreativitas.

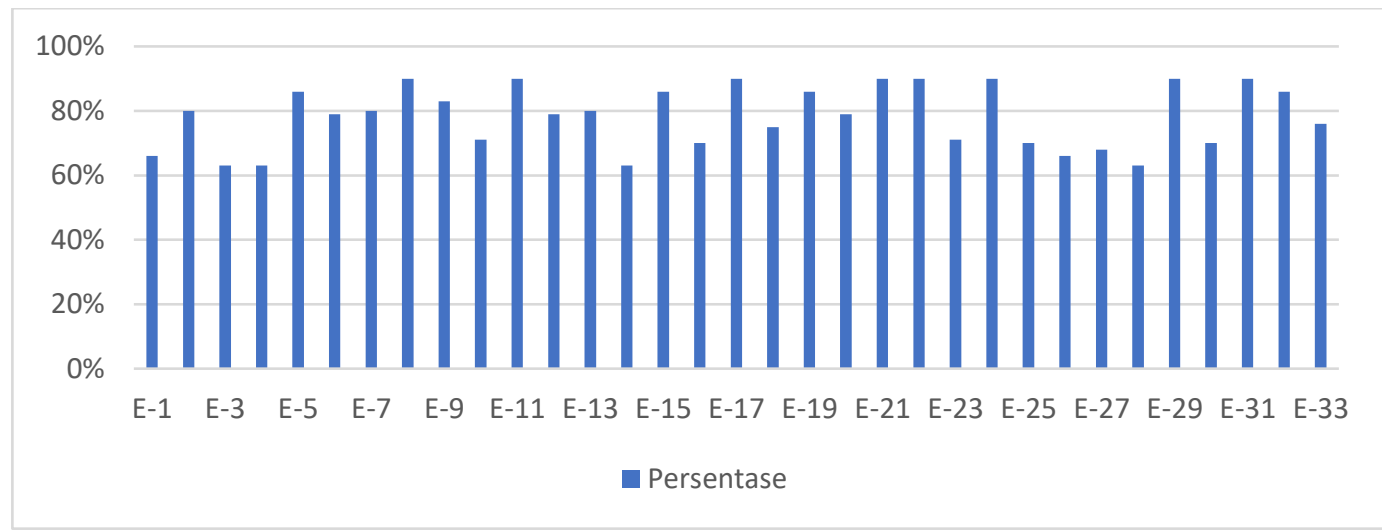

Gambar 2. Persentase Skor Kreativitas Siswa Kelas Eksperimen

Pada gambar, nilai rata-rata keseluruhan siswa adalah sebesar $78 \%$ dengan kriteria sedang. Jadi, bahwa disimpulkan adanya terdapat pengaruh model pembelajaran treffinger terhadap kreativitas siswa dalam proses belajar. Untuk mengetahui jawaban siswa pada masing-masing indikator yang telah ditentukan berdasarkan angket kreativitas siswa, seperti pada Gambar 3.

Berdasarkan hasil rata-rata per indikator angket kreativitas siswa. Pada indikator tidak takut mecoba hal-hal yang baru dengan nilai rata-rata siswa 75 kriteria sedang, pada indikator berusaha terus menerus agar berhasil yaitu 84 kriteria tinggi, selanjutnya indikator ketiga yaitu senang mecoba yang lebih sulit adalah 85 dengan kriteria tinggi. Kemudian pada indikator keempat tidak takut gagal dan kelima berani dalam mengakui suatu kegagalan dan berusaha lagi adalah 84 yang kriteria tinggi, pada indikator keenam adalah 81 , indikator ketujuh yaitu 78 yang kriterianya sedang, dan indikator kedelapan menghargai hak-hak sendiri dan orang lain adalah 68 pada kriteria sedang. Selanjutnya, indikator kesepuluh memikirkan lebih dari satu jawaban adalah 70 kriteria sedang, indikator kesebelas tidak takut menyatakan pemikiran dan perasaannya adalah 86 dengan kriteria tinggi, pada indikator kedua belas mencari banyak alternatif atau arah yang berbeda-beda yaitu 72 serta pada indikator ketiga belas menghasilkan gagasan, jawaban atau pertanyaan bervariasi yaitu 77 yang kriterianya sedang. Kemudian untuk indikator keempat belas dapat melihat suatu masalah dari sudut pandang yang berbeda-beda yaitu 75 yang 
berkriteria sedang. Untuk indikator kelima belas mempunyai kemauan keras untuk menyelesaikan soal yaitu 88 dengan kriteria tinggi. Untuk indikator keenam belas semangat untuk memberikan tanggapan yaitu 75 kriteria sedang. Untuk indikator ketujuh belas menambah atau merinci detail-detail dari suatu objek, gagasan, atau situasi sehingga menjadi lebih menarik, yaitu 79 berkriteria sedang. Untuk indikator kedelapan belas menanggapi pertanyaan-pertanyaan secara aktif dan semangat dalam menyelesaikan tugas-tugas yaitu 79 kriteria sedang. Untuk indikator kesembilan belas semangat dalam bertanya yaitu 75 kriteria sedang.

Tidak takut mencoba hal-hal yang baru

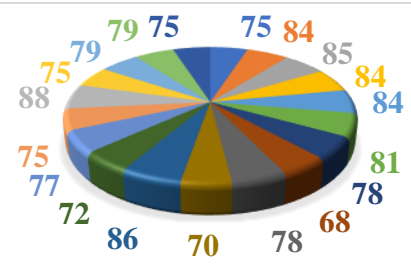

aberusaha terus menerus agar berhasil

四 senang mencoba yang lebih sulit

⿴囗十 tidak takut gagal

aberani dalam mengakui suatu kegagalan dan berusaha lagi

amenghargai hak-hak sendiri dan orang lain

menghargai kesempatan-kesempatan yang diberikan

alancar dalam mengemukakan ide

mencetuskan banyak ide, banyak jawaban banyak penyelesaian masalah, dan pertanyaan dengan lancar

国emikirkan lebih dari satu jawaban

a tidak takut menyatakan pemikiran \& perasaannya

mencari banyak alternatif dan arah berbeda-beda

⿴囗十 menghasilkan gagasan, jawaban atau pertanyaan yang bervariasi

⿴囗玉 dapat melihat suatu masalah dari sudut pandang yang berbeda-beda

बmempunyai kemauan keras untuk menyelesaikan soal-soal

⿴囗十memiliki semangat untuk memberikan tanggapan

बmenambah atau merinci detail-detail dari suatu objek, gagasan, atau situasi sehingga menjadi lebih menarik

amenanggapi pertanyaan secara semangat dalam menyelesaikan tugas-tugas

a semangat dalam bertanya

Gambar 3. Hasil Rata-Rata Per Indikator

Selain itu, nilai rata- rata keseluruhan perindikator adalah 78,48 dengan kriteria sedang. Artinya, dengan menggunakan model pembelajaran treffinger hampir semua siswa kelas eksperimen yang tingkat kreativitasnya dalam proses pembelajaran meningkat. Hal ini menunjukkan adanya model pembelajaran treffinger dapat peningkatkan kreativitas siswa dalam proses belajar.

Hasil tersebut sejalan dengan Rahmawati dkk. (2015) terdapat pengaruh yang signifikan model pembalajaran treffinger terhadap kreativitas siswa. kemudian, Mulyani dkk. (2017) yang juga menyatakan bahwa terdapat perbedaan keterampilan berpikir kreatif siswa yang signifikan di antara siswa dan model pembelajaran treffinger serta lainnya. Selain itu, Khairunnisa dkk. (2018) juga mengatakan model pembelajaran treffinger berpengaruh terhadap kreativitas siswa.

\section{Keterterapan Model Pembelajaran Treffinger}

Keterterapan treffinger berbantuan media gambar dilaksanakan di kelas eksperimen kelas VIII-7 dengan jumlah responden 33 orang siswa. pengukuran keterterapan model pembelajaran treffinger dilaksanakan dengan menggunakan lembar observasi. Pemberian skor penilaian dilakukan dua orang observer dan berlangsung selama proses pembelajaran. Penilaian terhadap keterterapan meliputi seluruh proses pembelajaran yang tertuang dalam rencana pembelajaran yaitu pendahuluan 
dan kegiatan inti serta kegiatan penutup. Pada Gambar 4 dapat dilihat keterterapannya sebanyak dua kali.

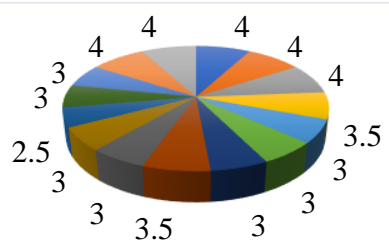

- Guru membuka pembelajaran dengan salam dan doa

- Guru memberikan apersepsi kepada siswa

- Guru menyampaikan tujuan pembelajaran

Guru menampilkan gambar dan mengajukan pertanyaan kepada siswa untuk mendorong keingintahuan siswa

- Guru menyajikan permasalahan untuk dipecahkan oleh siswa

- Guru mengarahkan siswa untuk memecahkan masalah

- Guru memberikan kesempatan kepada siswa untuk memunculkan ide berupa solusia penyelesaian masalah

- Guru membimbing siswa untuk mengungkapkan ide-ide penyelesaian masalah

- Guru mengarahkan siswa untuk menyepakati alternative ide untuk menyelesaikan masalah

- Guru meminta siswa untuk mengembangkan ide-ide yang telah disepakati sebagai alternatif penyelesaian masalah

- Guru mengarahkan siswa untuk mempresentasikan solusi penyelesaian masalah yang telah dikembangkan

- Guru mengarahkan siswa untuk meberikan tanggapan

- Guru mengarahkan siswa untuk bersama-sama memperbaiki solusi yang kelitu

- Guru mengarahkan siswa untuk menyampaikan kesimpulan mengenai materi yang telah dipelajari

- Guru menutup pembelajaran dengan doa dan salam

\section{Gambar 4. Hasil Observasi Keterterapan pembelajaran pertemuan 1}

Hasil dari gambar terlihat bahwa dalam pertemuan pertama adalah sebesar 3,37. Kemudian, mengetahui perkembangan keterterapan model pembelajar oleh peneliti yang melakukan dapat diperlihat pada pertemuan kedua atau pertemuan terakhir dalam penelitian.

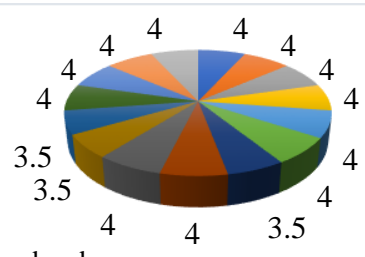

Guru membuka pembelajaran dengan salam dan doa

- Guru memberikan apersepsi kepada siswa

- Guru menyampaikan tujuan pembelajaran

Guru menampilkan gambar dan mengajukan pertanyaan kepada siswa untuk mendorong keingintahuan siswa

- Guru menyajikan permasalahan untuk dipecahkan oleh siswa

- Guru mengarahkan siswa untuk memecahkan masalah

- Guru memberikan kesempatan kepada siswa untuk memunculkan ide berupa solusi penyelesaian masalah

- Guru membimbing siswa untuk mengungkapkan ide-ide penyelesaian masalah

- Guru mengarahkan siswa untuk menyepakati alternative ide untuk menyelesaikan masalah

- Guru meminta siswa untuk mengembangkan ide-ide yang telah disepakati sebagai alternatif penyelesaian masalah

- Guru mengarahkan siswa untuk mempresentasikan solusi penyelesaian masalah yang telah dikembangkan

- Guru mengarahkan siswa untuk memberikan tanggapan

Guru mengarahkan siswa untuk Bersama-sama memperbaiki solusi yang keliru

- Guru mengarahkan siswa untuk menyampaikan kesimpulan mengenai materi yang dipelajari

Guru menutup pembelajaran dengan salam dan doa

\section{Gambar 5. Hasil Observasi Keterterapan Pembelajaran Pertemuan 2}

Hasil tersebut di atas menunjukkan bahwa pada pertemuan kedua, peneliti telah peningkatkan pembelajaran yang menerapinya seluruh proses pembelajaran yang tertuang dalam rencana pembelajaran yang sangat baik sehingga diperoleh rata-rata skor pada pertemuan pertama 3,37 dan pertemuan kedua sebesar 3,90. Selanjutnya, skor akhir keterterapan model pembelajaran treffinger berbantuan media gambar 
pada materi sistem peredaran darah berdasarkan skor rata-rata keseluruhan dapat diperhatikan dalam pada Gambar 6.

Hasil rata-rata observer dari kedua observer menunjukkan adanya peningkatan keterterapan model pembelajaran treffinger berbantuan media gambar dari setiap pertemuan. Hal tersebut dilihat pada gambar 6 yang mana pada pertemuan keduanya keseluruhan senilai 3,90 yang berkualifikasi sangat baik. Hasil tersebut sejalan dengan pendapat bahwa jika nilai rata-rata atau skor akhir lebih dari 3,254,00 maka kualifikasi interpretasi persentase keterterapan model pembelajaran adalah sangat baik (Fathonah, Indana \& Maulida, 2016).

- Guru membuka pembelajaran dengan salam dan do

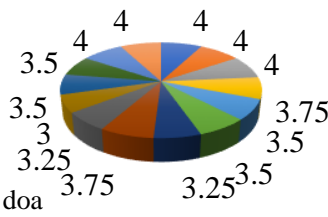

Guru memberikan apersepsi kepada siswa

- Guru menyampaikan tujuan pembelajaran

- Guru menampilkan gambar dan mengajukan pertanyaan kepada siswa untuk mendorong keingintahuan siswa

- Guru menyajikan permasalahan untuk dipecahkan oleh siswa

- Guru mengarahkan siswa untuk memecahkan masalah

- Guru memberikan kesempatan kepada siswa untuk memunculkan ide berupa solusi penyelesaian masalah

- Guru membimbing siswa untuk mengungkapkan ide-ide penyelesaian masalah

- Guru meminta siswa untuk mengembangakn ide-ide yang telah disepakati sebagai alternatif penyelesaian masalah

- Guru mengarahkan siswa untuk mempresentasikan solusi penyelesaian masalah yang telah dikembangkan

- Guru mengarahkan siswa untuk memberikan tanggapan

- Guru mengarahkan siswa untuk Bersama-sama memperbaiki solusi yang keliru

- Guru mengarahkan siswa untuk menyampaikan kesimpulan mengenai materi yang telah dipeajari

- Guru menutup pembelajaran dengan doa dan salam

\section{Gambar 6. Rata-Rata Hasil Observasi Keterterapan Pembelajaran}

Hasil tersebut sejalan dengan Sari (2016) serta Muhaiminu dan Nurhayati (2016) bahwa model pembelajaran treffinger dapat peningkatkan hasil belajar siswa. Kemudian Wirahayu, Purwito dan Juarti (2018) mengungkapkan model pembelajaran treffinger berpengaruh terhadap kemampuan berfikir. Selain itu, Beberapa penelitian (e.g. Sari \& Putra, 2016; Muliyani, Leny \& Suharto, 2017; Rifa'i, Sujana \& Romdonah, 2020; Akbar, Syaodih \& Lisnawati, 2015) juga menerangkan model pembelajaran treffinger dapat peningkat kemampuan berfikir kreatif siswa. Dengan demikian, model pembelajaran treffinger mempunyai pengaruh yang signifikan pada hasil belajar dan kreatifitas siswa.

\section{SIMPULAN}

Dapat disimpulkan dari penelitian yang dilakukan, terdapat adanya pengaruh model pembelajaran treffinger dengan berbantuan media gambar terhadap kreativitas dan hasil belajar siswa pada materi sistem peredaran darah.

\section{UCAPAN TERIMA KASIH}

Terimakasih kepada seluruh pihak yang tidak dapat disebutkan satu persatu yang telah memberikan baik membimbing, semangat, dan tempat sehingga penelitian ini dapat dilaksanakan dengan baik 


\section{REFERENSI}

Abdussalam, A. (2005). Mengembangkan Kreativitas Anak. Pustaka Al-Kautsar.

Akbar, P., Syaodih, E., \& Lisnawati, C. (2015). Efektivitas Model Pembelajaran Treffinger untuk Meningkatkan Kemampuan Berpikir Kreatif Siswa. Jurnal Pendidikan dan Pembelajaran Ekonomi Akuntansi, 1(1), 33-46.

Arikunto, S. (2006). Dasar-dasar Evaluasi Pendidikan. Jakarta: Bumi Aksara.

Cahyaningsih, U., \& Ghufron, A. (2016). Pengaruh Penggunaan Model ProblemBased Learning terhadap Karakter Kreatif dan Berpikir Kritis dalam Pembelajaran Matematika. Jurnal Pendidikan Karakter, 1(2). 104-115. https://doi.org/10.21831/jpk.v0i1.10736

Davis, G. A. (2012). Anak berbakat dan pendidikan keberbakatan. PT Indeks.

Fathonah, N., Indana, S., Maulida, A. N. (2016). Kelayakan Media Permainan IPA Edu Card Pada Materi Kalor dan Perpindahannya Bagi Siswa Kelas VII. Pensa: E-Jurnal Pendidikan Sains, 4(2), 1-6.

Huda, M. (2013). Model-Model Pengajaran dan Pembelajaran: Isu-Isu Metodis dan Paradigmatis. Pustaka Pelajar.

Insyasiska, D., Zubaidah, S., \& Susilo, H. (2017). Pengaruh Project Based learning terhadap motivasi belajar, kreativitas, kemampuan berpikir kritis, dan kemampuan kognitif siswa pada pembelajaran biologi. Jurnal Pendidikan Biologi, 7(1), 9-21. http://dx.doi.org/10.17977/um052v7i1p9-21

Jazuli, A. (2009). Berfikir kreatif dalam kemampuan komunikasi matematika. In Prosiding Seminar Nasional Matematika dan Pendidikan Matematika Jurusan Pendidikan Matematika FMIPA UNY (Vol. 2, pp. 209-220).

Juniantari, M. (2017). Pengembangan Perangkat Pembelajaran Matematika Berorientasi Pendidikan Karakter dengan Model Treffinger Bagi Siswa SMA. Journal of Education Technology, 1(2), 71-76. http://dx.doi.org/10.23887/jet.v1i2.11742

Muhaiminu, W. H., \& Nurhayati, S. (2016). Keefektifan Model Pembelajaran Treffinger Berbantuan Lembar Kerja Siswa untuk Meningkatkan Hasil Belajar. Jurnal Inovasi Pendidikan Kimia, 10(1), 1712-1720. https://doi.org/10.15294/jipk.v10i1.6017

Muhson, A. (2016). Pedoman Praktikum Analisis Statistik. Fakultas Ekonomi Univeritas Negeri Yogyakarta

Muliyani, M., Leny, L., \& Suharto, B. (2017). Pengaruh Model Pembelajaran Treffinger terhadap Kemampuan Berpikir Kreatif Dan Hasil Belajar Hidrolisis Garam Siswa Kelas Xi Ipa Sma Negeri 5 Banjarmasin Tahun Pelajaran 2016/2017. JCAE (Journal of Chemistry and Education), 1(1), 86-92.

Munandar, U. (1992). Mengembangkan Bakat dan Kreativitas Anak Sekolah. PT Grasindo

Nuryadi, N., Astuti, T. D., Utami, E. S., \& Budiantara, M. (2017). Dasar-Dasar Statistik Penelitian. Sibuku Media.

Rahmawati, L., Kurniawan, E. S., \& Ashari, A. (2015). Pengaruh Model Pembelajaran Treffinger Terhadap Kreativitas dan Hasil Belajar Suhu dan Kalor Siswa Kelas X SMA Negeri 3 Purworejo Tahun Pelajaran 2014/2015. Radiasi: Jurnal Berkala Pendidikan Fisika, 7(1), 26-31. 
Rifa'i, R., Sujana, A., \& Romdonah, I. (2020). Penerapan model pembelajaran treffinger untuk meningkatkan kemampuan berpikir kreatif matematis siswa. Jurnal Analisa, 6(1), 1-9. https://doi.org/10.15575/ja.v6i1.4365

Sanjaya, W. (2008). Strategi Pembelajaran Berorientasi Standar Proses Pendidikan. Kencana Prenada Media Group.

Sari, N. I. (2016). Penerapan Model Pembelajaran Treffinger dengan Bantuan Media Audio Visual Untuk Meningkatkan Aktivitas dan Hasil Belajar IPA Terpadu pada Siswa Kelas VII SMP Frater Makassar. Sainsmat: Jurnal Ilmiah Ilmu Pengetahuan Alam, 5(2), 167-174. https://doi.org/10.35580/sainsmat5232452016

Sari, Y. I., \& Putra, D. F. (2016). Pengaruh model pembelajaran treffinger terhadap kemampuan berpikir kritis dan kreatif mahasiswa Universitas Kanjuruhan Malang. Jurnal Pendidikan Geografi: Kajian, Teori, dan Praktek dalam Bidang Pendidikan dan Ilmu Geografi, 20(2), 30-38. http://dx.doi.org/10.17977/jpg.v20i2.290

Sugiyono. (2019). Metode Penelitian Pendidikan. Bandung: Alfabeta.

Wirahayu, Y. A., Purwito, H., \& Juarti, J. (2018). Penerapan model pembelajaran Treffinger dan ketrampilan berpikir divergen mahasiswa. Jurnal Pendidikan Geografi: Kajian, Teori, dan Praktek dalam Bidang Pendidikan dan Ilmu Geografi, 23(1), 30-40. http://dx.doi.org/10.17977/um17v23i12018p030 